\title{
The Use of Highly Diverse Clades As A Surrogate For Habitat Integrity Analysis: A Practical Tool For Rapid Assessments
}

\author{
María de Lourdes Gómez-Tolosa \\ Universidad de Ciencias y Artes de Chiapas \\ Enrique González-Soriano \\ Universidad Nacional Autonoma de Mexico \\ Luis Felipe Mendoza-Cuenca \\ Universidad Michoacana de San Nicolas de Hidalgo Facultad de Biologia \\ Ricardo M. Pérez-Munguía \\ Universidad Michoacana de San Nicolas de Hidalgo Facultad de Biologia \\ Tamara Mila Rioja-Paradela \\ Universidad de Ciencias y Artes de Chiapas \\ Eduardo Estanislao Espinoza-Medinilla \\ Universidad de Ciencias y Artes de Chiapas

\section{Héctor Ortega-Salas} \\ Universidad Nacional Autonoma de Mexico

\section{Gustavo Rivera-Velázquez} \\ Universidad de Ciencias y Artes de Chiapas \\ Fredi Eugenio Penagos- García \\ Universidad de Ciencias y Artes de Chiapas \\ Sergio López ( $\nabla$ sergio.lopez@unicach.mx ) \\ Universidad de Ciencias y Artes de Chiapas https://orcid.org/0000-0001-5173-7238
}

\section{Research Article}

Keywords: Abundance, Argia, Bioindicator, Damselflies, Diversity, Dragonflies, Habitat integrity, Odonata, Species Richness

Posted Date: July 23rd, 2021

DOI: https://doi.org/10.21203/rs.3.rs-595312/v1

License: (a) (1) This work is licensed under a Creative Commons Attribution 4.0 International License. Read Full License 


\section{Abstract}

Human activities have impacted many different habitat types on Earth, and there is a requirement for tools with which to accurately assess the level of damage incurred by ecosystems. For environmental analyses and monitoring, rapid stream assessment techniques emphasize geomorphological characteristics, biological potential, and habitat integrity characteristics. Using the principles and concepts of aquatic biology and ecology, we determined whether the visual-based habitat evaluation score is related to Odonata species diversity at different taxonomic levels. We hypothesized that habitat assessment is correlated positively with the local diversity of one Odonata taxonomic group. We found that the abundance, species richness, and diversity of Argia, one of the most locally diverse genera in southeastern Mexico, are positively correlated with habitat integrity scores. High richness (of up to eight species per site) corresponds to high integrity scores. Simultaneously, habitat integrity scores increase 23.51 times when Argia diversity (surface area) increases. We discuss the possible advantages of using a diverse Odonata clade (Argia) as a surrogate for local habitat assessments. Long-term biomonitoring programs could be applied using this novel approach in this specific Neotropical area. This study is framed within the focus of biodiversity and ecosystem functioning (BEF), however, it must be tested with other indices and a reliable and consistent relationship must be verified between diverse clades and environmental assessment scores.

\section{Introduction}

Ecosystems, both aquatic and terrestrial, face an unprecedented environmental crisis. The high number of extreme meteorological events (Luque et al., 2013), increased presence of chemicals with toxic effects on human health (Shen and Zuo, 2020) and loss of species (Dirzo et al. 2014) are three of the most critical challenges we currently face. Freshwater habitats in particular represent one of the world's most threatened ecosystems (Dudgeon et al., 2006; Voß \& Schäfer; 2017). For example, rivers ecosystems are increasingly affected by various factors as a result of the development of human activity (Valero et al., 2015). Maintenance of safe freshwater resources is therefore an urgent requirement worldwide, and there is a general trend towards examining threats over a broad range of scales, local to global, from both social and biological perspectives (Vörösmarty et al., 2010; Clausnitzer et al., 2012, Pinto et al., 2014).

River macrobenthic invertebrates have been widely reported and described as ecological indicators in the literature since the 1980s (Cairns \& van der Schalie, 1980; Chovanec \& Waringer, 2001; Ogbeibu \& Oribhabor, 2002; Clews et al., 2014). Ecological indicators have evolved from the use of simple metrics describing indicator taxa or measures of biological diversity to quality targeted and weighted indices of taxon sensitivity to specific stressors (Clews et al., 2014; Siddig et al., 2016), such as changes in physical and chemical water quality parameters, urbanization, deforestation, and pollution. Moreover, investigations of dragonfly and damselfly assemblages have become a reliable tool for ecological characterization and assessment of aquatic systems and evaluation of water management activities (Oertli, 2008; Bried and Samways, 2015).

Odonates are vital in the water bodies of aquatic ecosystems (Gómez-Tolosa et al., 2021). They are also ecologically important as dominant predators, while also constituting a significant prey for a considerable range of organisms and contributing a large proportion of total invertebrate biomass and species richness (Sahlén and Ekestubbe, 2001; Sang and Teder, 2011; Simaika and Samways, 2011). Many studies of ecological characterization (according to Chelli and Moulaï, 2019) are based on adult odonates because they are relatively easy to identify, collect and observe in situ (Silva et al., 2010; Simaika and Samways, 2011; Kutcher and Bried, 2014).

On the other hand, habitat assessment has been defined as evaluating the surrounding physical habitat structure that influences the quality of the water resource and the resident aquatic community (Barbour et al. 1996). An integral approach to assessing habitat structure includes evaluating substrate variety and quality, channel morphology, bank structure and riparian vegetation (Barbour et al., 1999). Rapid habitat assessments are often based on an observer rating the habitat integrity of the site by matching specific habitat features (Hannaford et al., 1997). Habitat assessments are, therefore, an efficient method for the characterization of stream habitat (Habberfield et al., 2014).

Therefore, there is a requirement for methods to identify pre-existing conditions and efficiently prioritize projects within stream corridors, especially in streams where data is sparse or non-existent (Habberfield et al., 2014). According to Habberfield et al. (2014), the most common and cost-effective methods used to identify and prioritize stream restoration sites include Visual-Based Rapid Assessment techniques that evaluate the quality of the physical conditions of the stream. Despite their common usage, few studies have related rapid assessment techniques with the macroinvertebrate communities, specifically with Odonata assemblages (e.g. Smith et al., 2007). Smith et al. (2007) hypothesized that a range of environmental conditions will place extreme demands on species 
composition at various sites (local scale). In contrast, other river systems would provide variation on a broader landscape scale. Rapid stream assessment techniques emphasize geomorphological characteristics as well as biological potential and parameters of habitat integrity (Barbour et al., 1999; Habberfield et al., 2014), whereas Odonata species are related to habitat conditions (Mendes et al., 2017; Carvalho et al., 2018) and probably reflect the proportion of specialists and generalists (Dolný et al., 2012; Šigutová et al., 2019). Indices featuring these species have been developed, including the Odonata Habitat Index (Chovanec and Waringer, 2001, Chovanec et al., 2015), Dragonfly Biotic Index (Simaika and Samways, 2009), Habitat Physical Integrity Score (HPIS) for adult odonates (Silva et al., 2010) and Coefficient of Conservatism (Kutcher and Bried, 2014).

Among other species, members of the Argia are related to high-quality habitat conditions (Azrina et al., 2006, Silva et al., 2010, Kutcher and Bried, 2014, Rodrigues et al., 2016, Valente-Neto et al., 2016, and Miguel et al., 2017). For example, Argia tinctipennis (Pinto et al., 2012), A. modesta (Silva et al., 2010) and A. reclusa (Juen et al., 2014) are related to high habitat integrity. In contrast, Argia collate (Calvão et al., 2016) and A. pulla (Gómez-Anaya et al., 2011; Gómez-Tolosa et al., 2015) have been reported as being tolerant to habitat disturbance. According to Cardinale et al. (2012), biodiversity can be used to predict some ecosystem functions (the BEF framework). In this context, we explore whether Odonata biodiversity can predict the habitat integrity. The objective in this study was to analyze the relationship between the Visual-Based Habitat Assessment Score (VBHAS; Barbour et al., 1999) and the parameters of abundance, species richness and diversity, at different taxonomic levels in streams of Neotropical basins. Specifically, we tested whether one taxonomic group can sufficiently explain habitat integrity to be of utility as a surrogate for rapid habitat assessment. We hypothesized that habitat assessment will correlate positively with a diverse clade, particularly the genus Argia because most of these species are typically specialists and thus sensitive to environmental quality (Šigutová et al., 2019), and could therefore be used as an indicator of habitat integrity in this specific area. We then compared the relationship using the information derived from General Linear Models (GLM). This comparison allows the discussion of techniques that attempt to correlate odonates diversity-specifically Argia diversityand habitat quality for local environmental assessments. Below, we discuss the possible use of Argia diversity for local long-term biomonitoring programs in tropical regions. However, we open the debate regarding the value of focusing on studying diverse clades as practical proxies of habitat integrity and verify whether there is a reliable and consistent relationship with other taxa and environmental indices, in the Neotropical region.

\section{Methods}

\section{Study site}

We carried out this study in three permanent basins, Cintalapa, Vado Ancho and Huixtla (Figure 1) in the region of Costa-Soconusco de Chiapas, southeastern Mexico (the geographic coordinates for the extremes of the study area are $15^{\circ} 30^{\prime} 59.25 \mathrm{~N}, 92^{\circ} 49^{\prime} 40.83 \mathrm{~W}$, and $14^{\circ} 55^{\prime} 50.41 \mathrm{~N} 92^{\circ} 12^{\prime} 42.40 \mathrm{~W}$ ). According to Köppen's climatic classification (modified by García, 2004, for Mexican conditions), the upstream region is classified as semi-warm humid, midstream as humid, and downstream as warm-sub humid with hot summers and dry winters. On average, the temperature in the hottest month is higher than $35.8^{\circ} \mathrm{C}$, whereas that of the coldest month is around 22.8 ${ }^{\circ} \mathrm{C}$. According to the Mexican Meteorological Service of the National Water Commission, the rainy season occurs from May to October, with annual rainfall ranging between 1200 and $3000 \mathrm{~mm}$ (30 years of periodic observations).

\section{Sampling method}

We delimited each sampling unit (SU) as an area of $15-20 \mathrm{~m}$ in length of the river with a 1 - $3 \mathrm{~m}$ wide strip of vegetation on either bank (depending on the topography and accessibility of each site). A total of 11 SUs were selected: three (numbers one, two and three) were along the Cintalapa basin (C), four (four, five, six and seven) were within the Vado Ancho basin (VA) and four (eight, nine, 10 and 11) were in the Huixtla basin $(\mathrm{H})$. We selected these SUs according to the goals of the project: "Inventory and comprehensive management program for the conservation of the Soconusco wetlands through their delimitation, ecological, hydrological, social characterization, and degree of risk" (Alonso Eguía-Lis et al., 2013), also considering other criteria such as the accessibility and other logistical factors, attempting to cover the streams along the basins. Each SU was characterized according to the combination of environmental conditions, river and locality name (for a detailed description, see Supplementary Material Appendix 1). To avoid the effect of spatial autocorrelation between SUs, we ran a Moran's autocorrelation Index (Supplementary Material Appendix 2). Each SU was visited three times throughout one complete hydrological cycle of the year. Sampling of adult dragonflies and damselflies took place in March 2012, September 2012, and January 2013 to cover both seasons: dry (March 2012 and January 2013) and rainy (September 2012). We captured mature adults in tandem (males and females), or mature male adults that exhibited territorial behavior, in order to facilitate taxonomic identification and ensure that the specimens sampled were breeding adults (Foote and Hornung, 2005; Bried et al., 2015; 
Chovanec et al., 2015; Patten et al., 2019). We collected insects using an entomological hand net between the hours of 09:30 and 15:30 hs., when the streams were illuminated by sunlight. Once species identification was completed, the individuals were released at their corresponding sampling sites. Where taxonomic identification in the field was not possible, each individual was preserved by placing in a cooler at $4{ }^{\circ} \mathrm{C}$ for at least 10 min to decrease the metabolism, then injected with $99 \%$ acetone and immersed for 24 hours in $99 \%$ acetone in order to preserve the original color. We carried out identification in the field and laboratory using taxonomic keys (Westfall \& May, 1996; Förster 2001; Garrison et al., 2010a; 2010b). Each identified specimen was subsequently compared with the species described for the state of Chiapas, according to González-Soriano and Paulson (2011).

\section{Visual-Based Habitat Assessment Score (VBHAS)}

We carried out the analyses of habitat quality for each SU according to a VBHAS proposed by Barbour et al. (1999) and adjusted for the area by Alonso Eguía-Lis et al. (2013) and Gómez-Tolosa et al. (2015). We included the riparian forest, riverbanks and channel structure related to human impact (Silva et al., 2010). Analyses of habitat quality for each SU were carried out according to a proposed VBHAS (Supplementary Material Appendix 3). Each unique feature was determined, and the scores were calculated as the sum of each value. A high score therefore reflects a better habitat condition. All parameters were evaluated and rated on a numerical scale of 0 to 20 (highest) for each SU. The ratings were then totaled and compared to a reference condition (according to Barbour et al., 1999; Supplementary Material Appendix 3) to provide a final habitat ranking. Kolem-Jaa-a site located on the state limits between Chiapas and Tabasco-was used as a reference site with which to compare the SU because of its null anthropogenic impact status and location within the same ecoregion. Scores rise with increasing habitat quality, and descriptions of the physical parameters and relative criteria were included in the rating form (Alonso Eguía-Lis et al., 2013) in order to ensure consistency in the evaluation procedure. The judgment criteria for each of the habitat parameters were calibrated for the stream classes under study, with some modifications applied on a regional basis. Each person was trained in the visual-based habitat assessment technique for the applicable region in order to give a particular score, after which the highest and lowest scores were eliminated, and the remaining estimations used to provide an average score for each SU. Habitat assessment was done in the driest month of the year (March 2012), during the odonate survey. At each visit to the $\mathbf{S U}$, water samples were taken and temperature, $\mathrm{pH}$, dissolved oxygen and conductivity were measured with a Hanna model HI-9829 Multiparameter. The average values that characterize each site are presented in the Supplementary Material Appendix 4.

\section{Statistical analyses}

Sampling representativeness was determined using the nonlinear Chao 2 estimator in the software EstimateS, Version 9.1. (Colwell, 2013). We ran the estimations for each taxonomic level, from order to genus. To analyze the relationship between VBHAS and the Odonata group, we calculated several diversity indices. The BioFTF package (Di Battista et al., 2016) was executed in R version 4.0.0 ( $R$ Core Team, 2020) using the interphase RStudio version 1.1.463 (RStudio Team, 2020) to calculate i) species richness (S), ii) Simpson's domination (D), iii) Shannon-Wiener diversity $\left(H^{\prime}\right)$ and iv) the area under the Beta diversity curve (hereafter referred to as surface area), which is a scalable measure that reflects the information provided by the biodiversity profile and allows ordering of communities with different richness values (as suggested by Di Battista et al., 2016. For more details, see Supplementary Material Appendix 5) at different taxonomic levels (from Odonata order to Argia genera). We used the package BioFTF to order ecological assemblages based on their biodiversity, considering both richness and evenness, avoiding the effect of differences between sample sizes and the number of species recorded (Supplementary Material Appendix 6).

As a dependent variable for the VBHAS data, we set the binomial distributions to Gaussian (normal), Poisson or Negative, using an $\mathrm{R}$ script for the dataset in the Supplementary Materials Appendix 7. To fit data distributions and find parameter estimates for those distributions, we used the package fitdistrplus (Delignette-Muller and Dutang, 2015). We performed all statistical analyses in RStudio version 1.1.463 (RStudio Team, 2020) for R, version 4.0.0 (R Core Team, 2020). To quantify the relationship between abundance, richness and diversity with the VBHAS, we ran a Beta and Dirichlet Regression Model according to Douma \& Weedon (2019), using the packages DirichletReg (Maier, 2020), ggplot2 (Wickham, 2016), betareg (Cribari-Neto \& Zeileis, 2010).

\section{Results}

During the sampling period, we recorded a total of 40 Odonata species from the following families: Libellulidae (16 spp.), Coenagrionidae (18 spp.), Protoneuridae (2 spp.) and Calopterygidae (4 spp.). A summary of all adult Odonata sampled by species is shown in Supplementary Material Appendix 9. Argia pulla was the only species recorded at all sites, while Argia pipila, Anatya guttata, 
Erythemis peruviana, Erythemis plebeja, Macrothemis extensa, Macrothemis inequiunguis, Paltothemis lineatipes and Tramea calverti were each recorded at only one SU. Within the Coenagrionidae, Argia had more species (13), which is consistent with results found at other localities in Mexico, where this genus has been reported to present the highest species richness.

The results of Moran's Index test showed that the SUs are spatially independent, in terms of VBHAS (Moran's Index $=0.0083, z$-score $=$ 0.488 and $p=0.625$ ). For the Odonata taxonomic level, with 512 individuals captured, $81.32 \%$ of the total expected species was reached; the Zygoptera suborder, with 469 individuals, presented $89.79 \%$ of the expected number of species; the Coenagrionidae family, with 363 individuals, reached 88.80\%; and Argia, with 351 individuals, reached 98.26\% (Figure 2).

Regarding the VBHAS for each SU, El Triunfo had the highest score with 199 points, whereas El Arenal presented the lowest score with 46 points (Supplementary Material Appendix 8). In general, the three sites at the lower part of the basin (El Arenal, Puente Teziutlán and El Palmar) presented the lowest scores, while the SU at the central part of the basin (El Triunfo, Zapote Mocho, and Huixtla) had the highest scores.

Independencia (SU 2) and Unión Hermosillo (SU 4) presented the highest species richness (13 species in each SU), whereas Puente Chorro presented the lowest richness, with only four species (Table 1). According to surface area (Table 1), the SU can be ordered from more diverse to less diverse as follows: Unión Hermosillo (SU 4), Zapote Mocho (SU 6), El Triunfo (SU 1), Independencia (SU 2), El Recuerdo (SU 5), Tolimán (SU 8), Huixtla (SU 10), Puente Chorro (SU 9), El Palmar (SU 7), El Arenal (SU 11) and Puente Teziutlán (SU 3).

Table 1. Results of diversity analyses in the 11 localities (SUs) along the rivers, from order to genera, and habitat integrity scores. Bold numbers indicate the highest value found for each variable.

\section{Sample Units (Localities)}

\begin{tabular}{llllllllllll} 
Variable & $\mathbf{1}$ & $\mathbf{2}$ & $\mathbf{3}$ & $\mathbf{4}$ & $\mathbf{5}$ & $\mathbf{6}$ & $\mathbf{7}$ & $\mathbf{8}$ & $\mathbf{9}$ & $\mathbf{1 0}$ & $\mathbf{1 1}$ \\
\hline Odonata abundance & 51 & 62 & 66 & 64 & 39 & $\mathbf{7 5}$ & 44 & 14 & 14 & 30 & 53 \\
\hline Odonata richness & 11 & 12 & 11 & $\mathbf{1 3}$ & 12 & 11 & 12 & 5 & 4 & 9 & 11 \\
\hline Odonata surface area & 5.98 & 6.35 & 5.17 & $\mathbf{6 . 9 3}$ & 6.81 & 6.03 & 6.01 & 3.57 & 2.94 & 5.42 & 4.92 \\
\hline Zygoptera abundance & 50 & 57 & 61 & 62 & 33 & $\mathbf{7 3}$ & 34 & 13 & 12 & 25 & 49 \\
\hline Zygoptera richness & 10 & 8 & 7 & $\mathbf{1 1}$ & 9 & 10 & 6 & 4 & 2 & 4 & 7 \\
\hline Zygoptera surface area & 5.63 & 4.97 & 3.73 & $\mathbf{6 . 2 9}$ & 5.62 & 5.66 & 3.49 & 3.02 & 1.73 & 3.33 & 3.45 \\
\hline $\begin{array}{l}\text { Coenagrionidae } \\
\text { abundance }\end{array}$ & 45 & 45 & 43 & 55 & 23 & $\mathbf{6 4}$ & 28 & 5 & 3 & 12 & 40 \\
\hline $\begin{array}{l}\text { Coenagrionidae } \\
\text { richness }\end{array}$ & 8 & 6 & 2 & $\mathbf{9}$ & 7 & 8 & 4 & 3 & 1 & 2 & 4 \\
\hline $\begin{array}{l}\text { Coenagrionidae surface } \\
\text { area }\end{array}$ & 4.78 & 4.04 & 0.87 & 5.41 & 4.60 & 4.76 & 2.22 & 3.00 & 1.33 & 1.90 & 1.78 \\
\hline Argia abundance & 44 & 45 & 42 & 53 & 21 & $\mathbf{6 4}$ & 25 & 5 & 3 & 12 & 37 \\
\hline Argia richness & 7 & 6 & 1 & $\mathbf{8}$ & 5 & $\mathbf{8}$ & 2 & 3 & 1 & 2 & 1 \\
\hline Argia surface area & 4.42 & 4.04 & 0.44 & $\mathbf{5 . 0 1}$ & 3.70 & 4.76 & 1.08 & 3.00 & 1.33 & 1.90 & 0.46 \\
\hline VBHAS & $\mathbf{1 9 9 . 0 0}$ & 143.00 & 92.00 & 135.00 & 174.00 & 195.00 & 51.0 & 150.00 & 168.00 & 189.00 & 46.0
\end{tabular}

In this preliminary rapid assessment study with Odonata, we found the following relationships: The GLM analysis showed a positive correlation between VBHAS and Argia species richness (S), with an estimated slope of $12.06 \pm 5.09$ (AIC $=119.30, p=0.04 ;$ Table 2, Figure 3a). For Coenagrionidae diversity (surface area), we found an estimated slope of $+20.03 \pm 9.36$ (AIC $=120.11, p=0.06$; Table 2, Figure $3 b$ ) and, for Argia diversity (surface area), the estimated slope was 23.51 \pm 7.16 (AIC $=115.97, p>0.01$; Table 2, Figure $3 c$ ). For Odonata and Zygoptera, we did not find any relationship with VBHAS for abundance, species richness, or diversity.

Table 2. General Linear Model summary for abundance, richness, and diversity, where $p$ is the probability of rejecting the null hypothesis and AIC corresponds to the Akaike Index Criteria. For all cases, $\mathrm{n}=11$. Bold numbers represent statistical significance for $p$ 


\begin{tabular}{llllll} 
& Taxonomic level & Coefficient & Standard error & $p$ & AIC \\
\hline \multirow{2}{*}{ ABUNDANCE } & Odonata & -0.27 & 0.9 & 0.77 & 124.52 \\
\cline { 2 - 6 } & Zygoptera & -0.05 & 0.9 & 0.95 & 124.62 \\
\cline { 2 - 6 } & Coenagrionidae & $8.90 \mathrm{E}-03$ & 0.09 & 0.99 & 124.63 \\
\cline { 2 - 6 } & Argia & 0.12 & 0.92 & 0.9 & 124.61 \\
\hline \multirow{2}{*}{ RICHNESS } & Odonata & -3.43 & 6.2 & 0.59 & 124.26 \\
\cline { 2 - 6 } & Zygoptera & 3.87 & 6.32 & 0.55 & 124.18 \\
\cline { 2 - 6 } & Coenagrionidae & 7.66 & 6.1 & 0.24 & 122.85 \\
\hline \multirow{2}{*}{ SURFACE AREA } & Orgia & $\mathbf{1 2 . 0 6}$ & $\mathbf{5 . 0 9}$ & $\mathbf{0 . 0 4}$ & $\mathbf{1 1 9 . 3}$ \\
\cline { 2 - 6 } & Zygonata & 4.84 & 14.57 & 0.75 & 124.49 \\
\cline { 2 - 6 } & Coenagrionidae & 20.03 & 9.36 & 0.06 & 122.74 \\
\cline { 2 - 6 } & Argia & $\mathbf{2 3 . 5 1}$ & $\mathbf{7 . 1 6}$ & $\mathbf{9 . 4 9 E}-03$ & $\mathbf{1 1 5 . 9 7}$ \\
& & 15.42 & 11.88 & 0.23 & 120.1 \\
\hline
\end{tabular}

\section{Discussion}

As expected, our results indicate that a highly diverse clade approach can be used to predict the environmental integrity of the streams in this study site. There is a growing need to identify rapid and effective biological indicators for measuring environmental health and quality (Kutcher and Bried, 2014; Voß and Schäfer, 2017). However, the use of indicator species has been criticized for several reasons, most notably the lack of justification given for selecting a particular indicator (Siddig et al., 2016). However, Mendoza-Penagos et al. (2021) recently demonstrated that a focus on odonate families for environmental monitoring could be advantageous in terms of costand time effectiveness and the quality of the information obtained. Moreover, these authors concluded that rapid assessments can be conducted effectively by selecting an adequate taxonomic level.

In this sense, adult damselflies and dragonflies (Odonata) have several attributes that make them appropriate for environmental evaluations (Dolný et al., 2012; Kutcher and Bried, 2014; Berquier et al., 2016; Miguel et al., 2017; Šigutová et al., 2019). Odonata species are increasingly used as indicators of water quality (Chovanec and Waringer, 2001; Simaika and Samways, 2009, 2011, 2012; Harabiš and Dolný, 2010; Silva et al., 2010; Kutcher and Bried, 2014; De Oliviera-Jr. et al., 2015; Berquier et al., 2016; Golfieri et al., 2016; Valente-Neto et al., 2016), multiple modalities of climatic change (Hassall, 2015), habitat integrity (Mendes et al., 2017), forest fragmentation (Renner et al., 2016), logging activities (Calvão et al., 2016), land use intensification (Rocha-Ortega et al., 2019) and the effects of urbanization (Bried and Samways, 2015). Pinto et al. (2012) demonstrated a higher wing fluctuating asymmetry in adults of Argia tinctipennis when riparian vegetation was removed, while Rocha-Ortega et al. (2019) showed that adult Odonata body size seems to be a more suitable variable for measuring the integrity of original vegetation than the more commonly used species richness indices.

In tropical regions, nine Odonata species were classified as useful indicators of ecosystem health (De Oliviera-Jr. et al., 2015). Four of these have been associated with more degraded streams (three species from Anisoptera and one from Zygoptera), while five Zygoptera species were indicative of optimal environmental conditions (De Oliviera-Jr. et al., 2015). These findings suggest the use of sets of species that are sensitive to environmental conditions.

The SUs downstream were lower in habitat integrity (measured with the VBHAS) since they presented a low score for velocity (depth regimes), with categories of poor quality in El Palmar (SU7) and El Arenal (SU11). This is in contrast to the midstream and upstream SUs, which present optimum and suboptimum habitat integrity, respectively. Some species, such as Argia pipila and A. pocomana, are associated with riffles, while other species are associated with pools (Erythemis plebeja, Neoerythromma cultellatum, Tramea calverti). Accordingly, further studies of rapid assessments have found that Argia modesta (Silva et al., 2010) and A. indocilis (Dalzochio et al., 2011) are abundant in sites with higher habitat integrity scores. In contrast, Montero-Junior et al. (2015) found that the population size 
of Argia species decreased when areas of urbanization and deforestation increased. Consequently, the mixture of specialist and generalist species acted to conceal the relationship with VBHAS, which was evaluated at a higher taxonomic level (order).

Classical species diversity measures use species richness, heterogeneity or evenness; however, as Magurran (2004) stated, no index is universally applicable across all ecological assemblages. Consequently, there is no single index that can summarize species diversity concepts (Whittaker, 1972; Purvis and Hector, 2000; Morris et al., 2014). Traditional diversity indices represent various phenomena because some indices prioritize species richness over uniformity (or vice versa). As a result, communities could be ranked differently depending on the index applied (Hurlbert, 1971). According to Stirling and Wilsey (2001), species diversity should be measured using a compound statistical metric. Since traditional diversity indices cannot summarize species diversity, a composite statistical measure is required (Guisande et al., 2017). In this context, Di Battista et al. (2016) provide a scalar measure that leads to a community classification, using the area under the curvature function (Supplementary Material Appendix 5) and avoiding bias towards either dominant or rare species.

Moreover, previous studies have analyzed the relationship between biotic (Simaka and Samways, 2011) and habitat integrity indices (Alves-Martins et al. 2018, De Oliveira-Junior and Juen, 2019), using estimates of diversity. Our study includes an analysis of the total diversity, abundance and species richness of odonates at different taxonomic levels (order, sub-order, family, and genera) with a habitat integrity index (VBHAS). We found that Argia species richness and diversity both increase with increasing habitat integrity indices. This relationship means that analysis at the genus level could be more accurate than at higher taxonomic levels for this particular region.

Unfortunately, little is known regarding the life cycles, geographic distribution and tolerance to environmental change of many odonate species in this region. It is therefore difficult to relate the environmental factors that affect each life cycle stage to presence or absence in a particular site. For this reason, we found insufficient information for this specific Neotropical region to compare our results with other indices; for example, the Odonata Habitat Index (Chovanec and Waringer, 2001) or the Dragonfly Biotic Index (Simaika and Samways, 2009).

Moreover, Raebel et al. (2010), Patten et al. (2015), Bried et al. (2016), Khelifa (2019) and Šigutová et al. (2019) discussed the advantages and disadvantages of using the adult stage and concluded that adult-based bioassessment methods are reliable and easily applied to various types of tropical forest habitats worldwide. For this study, we monitored a complete hydrological cycle using only resident adults and insects that showed any reproductive activity, such as tandem or oviposition behavior.

With regard to our hypothesis, we suggested that habitat assessment will correlate positively with a diverse clade, particularly the speciose Argia genus, and therefore expected a positive relationship since most of these species are typically running water specialists and sensitive to environmental integrity. Moreover, since these species belong to the same clade, they must share a common evolutionary and colonization history in this specific area. We found a robust positive relationship between VBHAS with Argia richness and diversity, regardless of geographic position (latitude, longitude, and elevation). Habitat integrity scores increase 12.06 times when Argia species richness increases. At the same time, habitat integrity scores increase 23.51 times when Argia diversity (surface area) increases, which is consistent with the theoretical fundamentals of rapid assessment evaluation (Azrina et al., 2006; Harabiš and Dolný, 2010; Harabiš and Dolný, 2012).

El Triunfo, the SU with the highest VBHAS, has eight of the 13 Argia species; and Zapote Mocho, the SU with the second highest VBHAS, has nine of the 13 Argia species, two of which are exclusive to this site, supporting the notion that Argia species are better indicators of habitat integrity. These results coincide with those of other studies that have related habitat quality to species of the Suborder Zygoptera (Dutra and De Marco, 2015; Monteiro-Júnior et al., 2015; Rodrigues et al., 2016) and the genus Argia (NoveloGutiérrez and Gómez-Anaya, 2009; Silva et al., 2010; Calvão et al., 2016).

In terms of establishing monitoring protocols for each of the three Soconusco basins in this region, environmental quality assessment is more efficient when using only the genus Argia (13 spp.) rather than all of the odonate species (40 spp.). Previous studies have shown a relationship between species assemblage and habitat integrity. For example, Miguel et al. (2017) and Schöder et al. (2020) found that Argia species were abundant under better habitat conditions (i.e., using an index of habitat integrity proposed by Nessimian et al., 2008).

The study of Mendoza-Penagos et al. (2021) found that abundance had the highest concordance with habitat integrity variations at the Coenagrionidae level, while that of Valente-Neto et al. (2016) focused on the genus composition. However, to our knowledge, no specific studies have used a diverse species clade belonging to Argia with habitat integrity indices. Argia occurs throughout the New

Page $7 / 15$ 
World, with its highest diversity found in our study area (Caesar \& Wenzel, 2009). Our approach also differs in that we tested different taxonomic levels (from order to genera) as predictors of habitat integrity. Nevertheless, this approach must be tested with other quality indices and other highly diverse clades in order to determine its accuracy.

\section{Conclusions}

Odonata species are of value to the assessment of lotic habitat integrity, especially in Neotropical ecosystems. However, when we compare the results obtained from the analyses between the different diversity indices and the VBHA scores, the parameters of richness and diversity were significant for Argia species.

This study demonstrates that it is possible to monitor Argia species associated with environmental integrity, preserved environments, and degraded streams, and the results show that species richness and diversity are both positively related to the visual habitat integrity index (VBHAS) scores in this Neotropical zone. Argia diversity has the lowest AIC value of all analyzed models.

This monitoring method can be applied by local people with no specialized biological training. However, further fieldwork is necessary before establishing monitoring protocols. More data are required through the collection of female specimens to develop a field guide that helps the identification of specimens by local non-specialist monitors.

We recommend the use of diverse clades for evaluating environmental integrity in order to test our hypothesis. We strongly suggest using odonates and other taxa for rapid environmental evaluations in the Neotropical region.

\section{Declarations}

\section{Ethics approval and consent to participate}

Not applicable

\section{Consent for publication}

Not applicable

\section{Availability of data and materials}

All data generated and analyzed during this study are included in this published article as supplementary information files.

\section{Competing interests}

The authors declare that they have no competing interests.

\section{Funding}

This work was supported by the CONAGUA-CONACYT under-18 months master's grant for thesis number 2010-02-agreement 148109, for María Gómez-Tolosa.

\section{Authors' contributions}

Conceptualization: MGT, EGS, SL; Methodology: MGT, SL; Formal analysis and investigation: MGT, EGS, LFMC, SL; Writing - original draft preparation: MGT, SL; Writing - review and editing: EGS, LFMC, RMPM, TMRP, HOS, GRV, FEPG; Funding acquisition: EEEM; Resources and supervision: EGS, LFMC, SL; Software and visualization: MGT, SL.

\section{Acknowledgments}

We thank the Mexican Council for Science and Technology (CONACYT) and the Mexican Water Council (CONAGUA) for funding this research. Thanks also go to Keith MacMillan, George Damoff, Felicia Line and Francisca Méndez-Harclerode for linguistic corrections, and all those who helped us during field collections and with species identification in the laboratory; Daniel Alberto Martínez, Maricela Gómez Cristiani, Artemio González, Rocío B. Gómez Gutiérrez, Diego and Mario López. This work was supported by the CONAGUA- 
CONACYT under-18 months master's grant for thesis number 2010-02-agreement 148109, for María Gómez-Tolosa. This paper is dedicated to the memory of Jorge Tolosa and Amalia Mendoza.

\section{References}

1. Alonso Eguía-Lis PE, Brena Zepeda J, Castillo C, et al. (2013) Inventario y programa de manejo integral para la conservación de los humedales del Soconusco a través de su delimitación, caracterización ecológica, hidrológica, social y grado de riesgo. Informe Final, CONAGUA-CONACyT, Convenio 148109. México.

2. Alves-Martins F, Calatayud J, Medina NG, et al (2019) Drivers of regional and local diversity of Amazonian stream Odonata. Insect Conserv Divers 12:251-261. https://doi.org/10.1111/icad.12327

3. Azrina MZ, Yap CK, Rahim Ismail A, et al (2006) Anthropogenic impacts on the distribution and biodiversity of benthic macroinvertebrates and water quality of the Langat River, Peninsular Malaysia. Ecotoxicol Environ Saf 64:337-347. https://doi.org/10.1016/j.ecoenv.2005.04.003

4. Barbour MT, Diamond JM, Yoder CO (1996) Biological assessment strategies: Applications and Limitations. In: Grothe D, Dickson KL, Reed-Judkins DK (eds) Whole effluent toxicity testing: An evaluation of methods and prediction of receiving system impacts, SETAC Press, Pensacola, Florida: 245-270.

5. Barbour MT, Gerritsen J, Snyder BD, Stribling JB (1999) Rapid bioassessment protocols for use in streams and wadeable rivers: periphyton, benthic macroinvertebrates and fish. In: US Environmental Protection Agency Office of Water Washington DC (Vol. 2nd). https://doi.org/EPA 841-B-99-002

6. Berquier C, Orsini A, Ferrat L, Andrei-Ruiz MC (2016) "Odonata Community Index - Corsica" (OCIC): A new biological index based on adult odonate populations for assessment of the ecological status of watercourses in Corsica. Ecological Indicators, 66:163-172. https://doi.org/10.1016/j.ecolind.2016.01.022

7. Bried JT, Samways MJ (2015) A review of odonatology in freshwater applied ecology and conservation science. Freshw Sci 34:1023-1031. https://doi.org/10.1086/682174

8. Calvão LB, Nogueira DS, de Assis Montag LF, Lopes MA, Juen L (2016) Are Odonata communities impacted by conventional or reduced impact logging? Forest Ecology and Management 382: 143-150. https://doi.org/10.1016/j.foreco.2016.10.013

9. Cardinale BJ, Duffy JE, Gonzalez A, et al (2012) Biodiversity loss and its impact on humanity. Nature 486:59-67. https://doi.org/10.1038/nature11148

10. Carvalho FG, de Oliveira Roque F, Barbosa L, et al (2018) Oil palm plantation is not a suitable environment for most forest specialist species of Odonata in Amazonia. Anim Conserv 21:526-533. https://doi.org/10.1111/acv.12427

11. Chelli A, Moulaï R (2019) Ecological characterization of the odonatofauna in lotic and lentic waters of northeast Algeria. Ann la Société Entomol Fr 55:430-445. https://doi.org/10.1080/00379271.2019.1660215

12. Chovanec A, Schindler M, Waringer J, Wimmer R (2015) The dragonfly association index (Insecta: Odonata)-a tool for the typespecific assessment of lowland rivers. River Res Appl 31:627-638. https://doi.org/10.1002/rra.2760

13. Chovanec A, Waringer J (2001) Ecological integrity of river-floodplain systems - assessment by dragonfly surveys (Insecta: Odonata). River Res Appl 17:493-507. https://doi.org/10.1002/rrr.664

14. Clausnitzer V, Dijkstra KDB, Koch R, et al (2012) Focus on African freshwaters: Hotspots of dragonfly diversity and conservation concern. Front Ecol Environ 10:129-134. https://doi.org/10.1890/110247

15. Clews E, Low EW, Belle CC, et al (2014) A pilot macroinvertebrate index of the water quality of Singapore's reservoirs. Ecol Indic 38:90-103. https://doi.org/10.1016/j.ecolind.2013.10.030

16. Colwell RK (2013) EstimateS: Statistical estimation of species richness and shared species from samples, Version 9. User's Guide and application published at: http://purl.oclc.org/estimates.

17. Crains Jr J, Van Der Schalie WH (1980) Biological monitoring part 1-Eearly Warning Systems. Water Res 14:1179-1196.

18. de Oliveira-Junior JMB, Shimano Y, Gardner TA, et al (2015) Neotropical dragonflies (Insecta: Odonata) as indicators of ecological condition of small streams in the eastern Amazon. Austral Ecol 40:733-744. https://doi.org/10.1111/aec.12242

19. Cribari-Neto F, Zeileis A (2010) Beta Regression in R. Journal of Statistical Software, 34: 1-24. doi: 10.18637/jss.v034.i02 (URL: https://doi.org/10.18637/jss.v034.i02) 
20. Dalzochio MS, Costa JM, Uchôa MA (2011) Diversity of Odonata (Insecta) in lotic systems from Serra da Bodoquena, Mato Grosso do Sul State, Brazil. Rev Bras Entomol 55:88-94. https://doi.org/10.1590/S0085-56262011000100014

21. De Oliveira Júnior JMB, Juen L (2019) The Zygoptera/Anisoptera Ratio (Insecta: Odonata): a New Tool for Habitat Alterations Assessment in Amazonian Streams, Neotropical Entomology, 48:552-560. https://doi.org/10.1007/s13744-019-00672-x

22. Delignette-Muller ML, Dutang C (2015) fitdistrplus: An R Package for Fitting Distributions. Journal of Statistical Software, 64:1-34.

23. Di Battista T, Fortuna F, Maturo F (2016) Environmental monitoring through functional biodiversity tools. Ecol Indic 60:237-247. https://doi.org/10.1016/j.ecolind.2015.05.056

24. Dirzo R, Young HS, Galetti M, et al (2014) Defaunation in the Anthropocene. Science (80- ) 345:401-406. https://doi.org/10.1126/science.1251817

25. Dolný A, Harabiš F, Barta D, et al (2012) Aquatic insects indicate terrestrial habitat degradation: changes in taxonomical structure and functional diversity of dragonflies in tropical rainforest of East Kalimantan. Trop Zool 1-17.

https://doi.org/10.1080/03946975.2012.717480

26. Douma JC, Weedon JT (2019) Analysing continuous proportions in ecology and evolution: A practical introduction to beta and Dirichlet regression. Methods Ecol Evol 10:1412-1430. https://doi.org/10.1111/2041-210X.13234

27. Dudgeon D, Arthington AH, Gessner MO, et al (2006) Freshwater biodiversity: importance, threats, status and conservation challenges. Biol Rev 81:163. https://doi.org/10.1017/S1464793105006950

28. Foote AL, Rice Hornung CL (2005) Odonates as biological indicators of grazing effects on Canadian prairie wetlands. Ecol Entomol 30:273-283. https://doi.org/10.1111/j.0307-6946.2005.00701.x

29. Förster S (2001) The Dragonflies of Central America exclusive of Mexico and the West Indies. A Guide to their Identification, 2nd. Edition. G. Rehfeldt, Wolfenbüttel, Germany.

30. Garrison RW, Von Ellenrieder N, Louton JA (2010a) Dragonfly Genera of the New World. An illustrated and annotated key to the Anisoptera, The Johns Hopkins University Press, Baltimore, USA.

31. Garrison RW, Von Ellenrieder N, Louton JA (2010b) Damselfly Genera of the New World. An illustrated and annotated key to the Zygoptera, The Johns Hopkins University Press, Baltimore, USA.

32. Golfieri, B., Hardersen, S., Maiolini, B., \& Surian, N. (2016). Odonates as indicators of the ecological integrity of the river corridor: Development and application of the Odonate River Index (ORI) in northern Italy. Ecological Indicators, 61, 234-247. https://doi.org/10.1016/j.ecolind.2015.09.022

33. Gómez-Anaya JA, Novelo-Gutiérrez R, Campbell WB (2011) Diversity and distribution of odonata (Insecta) larvae along an altitudinal gradient in coalcomán mountains, michoacán, Mexico. Rev Biol Trop 59:1559-1577.

https://doi.org/10.15517/rbt.v59i4.3420

34. Gómez-Tolosa M de L, Mendoza-Cuenca LF, Rioja-Paradela TM, et al (2015) Odonata (Insecta) de tres cuencas en la costa de Chiapas: Lista de especies y registro nuevo. Rev Mex Biodivers 86:41-47. https://doi.org/10.7550/rmb.48665

35. Gómez-Tolosa M, Rivera-Velázquez G, Rioja-Paradela TM, et al (2021) The use of Odonata species for environmental assessment: a meta-analysis for the Neotropical region. Environ Sci Pollut Res 28: 1381-1396. https://doi.org/10.1007/s11356-020-11137-9

36. González-Soriano E, Paulson DR (2011) Odonata de Chiapas. 299-314. En: Álvarez-Noguera F (Ed.). Chiapas: Estudios sobre su diversidad biológica, Instituto de Biología y Dirección General de Publicaciones, UNAM. Distrito Federal, México.

37. Guisande, C., Heine, J., García-Roselló, E., González-Dacosta, J., Vilas, L. G., \& Perez-Schofield, B. J. G. (2017). DER: An algorithm for comparing species diversity between assemblages. Ecological Indicators, 81, 41-46.

https://doi.org/10.1016/j.ecolind.2017.05.049

38. Habberfield MW, Blersch SS, Bennett SJ, Atkinson JF (2014) Rapid Geomorphic and Habitat Stream Assessment Techniques Inform Restoration Differently Based on Levels of Stream Disturbance. J Am Water Resour Assoc 50:1051-1062. https://doi.org/10.1111/jawr.12156

39. Hannaford MJ, Barbour MT, Resh VH (1997) Training reduces observer variability in visual-based assessments of stream habitat. J North Am Benthol Soc 16:853-860. https://doi.org/10.2307/1468176

40. Harabiš F, Dolný A (2012) Human altered ecosystems: Suitable habitats as well as ecological traps for dragonflies (Odonata): The matter of scale. J Insect Conserv 16:121-130. https://doi.org/10.1007/s10841-011-9400-0

41. Hassall C (2015) Odonata as candidate macroecological barometers for global climate change. Freshw Sci 34:1040-1049. https://doi.org/10.1086/682210

Page 10/15 
42. Hurlbert, S. H. (1971). The Nonconcept of Species Diversity: A Critique and Alternative Parameters. Ecology, 52(4), 577-586. https://doi.org/10.1016/S0140-6736(00)02805-1

43. Juen L, Oliveira-Junior JMBD, Shimano Y, Mendes TP, Cabette HSR (2014) Composition and richness of Odonata (Insecta) in streams with different levels of conservation in a Cerrado-Amazonian Forest ecotone. Acta Amazonica 44:223-233. http://dx.doi.org/10.1590/S0044-59672014000200008

44. Kutcher TE, Bried JT (2014) Adult Odonata conservatism as an indicator of freshwater wetland condition. Ecol Indic 38:31-39. https://doi.org/10.1016/j.ecolind.2013.10.028

45. Luque GM, Hochberg ME, Holyoak M, et al (2013) Ecological effects of environmental change. Ecol Lett 16:1-3. https://doi.org/10.1111/ele.12050

46. Maier MJ (2020) DirichletReg: Dirichlet Regression in R. R package version 0.7-0. http://dirichletreg.r-forge.r-project.org/

47. Mendes TP, Oliveira-Junior JMB, Cabette HSR, et al (2017) Congruence and the Biomonitoring of Aquatic Ecosystems: Are Odonate Larvae or Adults the Most Effective for the Evaluation of Impacts. Neotrop Entomol 46:631-641. https://doi.org/10.1007/s13744017-0503-5

48. Mendoza-Penagos CC, Calvão LB, Juen L (2021) A new biomonitoring method using taxonomic families as substitutes for the suborders of the Odonata (Insecta) in Amazonian streams. Ecol Indic 124:. https://doi.org/10.1016/j.ecolind.2021.107388

49. Miguel TB, de Oliveira-Junior JMB, Ligeiro R, Juen L (2017) Odonata (Insecta) as a tool for the biomonitoring of environmental quality. Ecol Indic 81:555-566. https://doi.org/10.1016/j.ecolind.2017.06.010

50. Monteiro Júnior CDS, Juen L, Hamada N (2015) Analysis of urban impacts on aquatic habitats in the central Amazon basin: Adult odonates as bioindicators of environmental quality. Ecological Indicators, 48:303-311. https://doi.org/10.1016/j.ecolind.2014.08.021

51. Morris EK, Caruso T, Buscot F, et al (2014) Choosing and using diversity indices: Insights for ecological applications from the German Biodiversity Exploratories. Ecol Evol 4:3514-3524. https://doi.org/10.1002/ece3.1155

52. Oertli B (2008) The use of dragonflies in the assessment and monitoring of aquatic habitats. In: Córdoba-Aguilar A (ed) Dragonflies and Damselflies: Model Organisms for Ecological and Evolutionary Research, 1st edn. Oxford University Press Inc., Oxford, UK, pp 79-95

53. Ogbeibu AE, Oribhabor BJ (2002) Ecological impact of river impoundment using benthic macro-invertebrates as indicators. Water Res 36:2427-2436.

54. Patten MA, Hjalmarson EA, Smith-Patten BD, Bried JT (2019) Breeding thresholds in opportunistic Odonata records. Ecol Indic 106:105460. https://doi.org/10.1016/j.ecolind.2019.105460

55. Pinto NS, Juen L, Cabette HSR, de Marco P (2012) Fluctuating Asymmetry and Wing Size of Argia tinctipennis Selys (Zygoptera: Coenagrionidae) in Relation to Riparian Forest Preservation Status. Neotrop Entomol 41:178-185. https://doi.org/10.1007/s13744-012-0029-9

56. Purvis A, Hector A (2000) Getting the measure of biodiversity. Nature, 405; 212-219.

57. R Core Team (2020) R: A language and environment for statistical computing, R Foundation for Statistical Computing, Vienna, Austria. URL https://www.R-project.org/.

58. Renner S, Sahlén G, Périco E (2016) Testing Dragonflies as Species Richness Indicators in a Fragmented Subtropical Atlantic Forest Environment. Neotrop Entomol 45:231-239. https://doi.org/10.1007/s13744-015-0355-9

59. Rocha-Ortega M, Rodríguez P, Córdoba-Aguilar A (2019) Can dragonfly and damselfly communities be used as bioindicators of land use intensification? Ecol Indic 107:. https://doi.org/10.1016/j.ecolind.2019.105553

60. Rodrigues ME, de Oliveira Roque F, Quintero JMO, et al (2016) Nonlinear responses in damselfly community along a gradient of habitat loss in a savanna landscape. Biol Conserv 194:113-120. https://doi.org/10.1016/j.biocon.2015.12.001

61. RStudio Team (2020) RStudio: Integrated Development Environment for R, (accessed 3 March 2020).

62. Sahlen G, Ekestubbe K (2001) Identification of dragonflies (Odonata) as indicators of general species richness in boreal forest lakes. Biodivers Conserv 10:673-690.

63. Sang A, Teder T (2011) Dragonflies cause spatial and temporal heterogeneity in habitat quality for butterflies. Insect Conserv Divers 4:257-264. https://doi.org/10.1111/j.1752-4598.2011.00134.x

64. Shen C, Zuo Z (2020) Zebrafish (Danio rerio) as an excellent vertebrate model for the development, reproductive, cardiovascular, and neural and ocular development toxicity study of hazardous chemicals. Environ Sci Pollut Res 27:43599-43614.

Page $11 / 15$ 
https://doi.org/10.1007/s11356-020-10800-5

65. Schröder NM, Rippel CG, Walantus LH, Zapata PD (2020) Odonata assemblages as indicators of stream condition a test from northern Argentina. North Western Journal of Zoology 16: 117-124.

https://biozoojournals.ro/nwjz/content/v16n2/nwjz_e201101_Schroder.pdf.

66. Siddig AAH, Ellison AM, Ochs A, et al (2016) How do ecologists select and use indicator species to monitor ecological change? Insights from 14 years of publication in Ecological Indicators. Ecol Indic 60:223-230. https://doi.org/10.1016/j.ecolind.2015.06.036

67. Šigutová H, Šipoš J, Dolný A (2019) A novel approach involving the use of Odonata as indicators of tropical forest degradation: When family matters. Ecol Indic 104:229-236. https://doi.org/10.1016/j.ecolind.2019.05.001

68. Silva D de paiva, De Marco P, Resende DC (2010) Adult odonate abundance and community assemblage measures as indicators of stream ecological integrity: A case study. Ecol Indic 10:744-752. https://doi.org/10.1016/j.ecolind.2009.12.004

69. Simaika JP, Samways MJ (2009) An easy-to-use index of ecological integrity for prioritizing freshwater sites and for assessing habitat quality. Biodivers Conserv 18:1171-1185. https://doi.org/10.1007/s10531-008-9484-3

70. Simaika JP, Samways MJ (2011) Comparative assessment of indices of freshwater habitat conditions using different invertebrate taxon sets. Ecol Indic 11:370-378. https://doi.org/10.1016/j.ecolind.2010.06.005

71. Smith J, Samways MJ, Taylor S (2007) Assessing riparian quality using two complementary sets of bioindicators. Biodivers Conserv 16:2695-2713. https://doi.org/10.1007/s10531-006-9081-2

72. Stirling G, Wilsey B (2001) Empirical relationships between species richness, evenness, and proportional diversity. Am Nat 158:286-299. https://doi.org/10.1086/321317

73. Valente-Neto F, De Oliveira Roque F, Rodrigues ME, et al (2016) Toward a practical use of Neotropical odonates as bioindicators: Testing congruence across taxonomic resolution and life stages. Ecol Indic 61:952-959. https://doi.org/10.1016/j.ecolind.2015.10.052

74. Valero E, Álvarez X, Picos J (2015) An assessment of river habitat quality as an indicator of conservation status. A case study in the Northwest of Spain. Ecol Indic 57:131-138. https://doi.org/10.1016/j.ecolind.2015.04.032

75. Voß K, Schäfer RB (2017) Taxonomic and functional diversity of stream invertebrates along an environmental stress gradient. Ecol Indic 81:235-242. https://doi.org/10.1016/J.ECOLIND.2017.05.072

76. Vörösmarty CJ, McIntyre PB, Gessner MO, et al (2010) Global threats to human water security and river biodiversity. Nature 468:334-334. https://doi.org/10.1038/nature09549

77. Westfall MJ, May ML (1996) Damselflies of North America, Scientific Publishers, Gainesville FL.

78. Wickham H (2016) ggplot2: Elegant Graphics for Data Analysis, Springer-Verlag, New York.

79. Whittaker, R. H. (1972). Evolution and measurement of species diversity. Taxon 21: 213- 251.

\section{Figures}




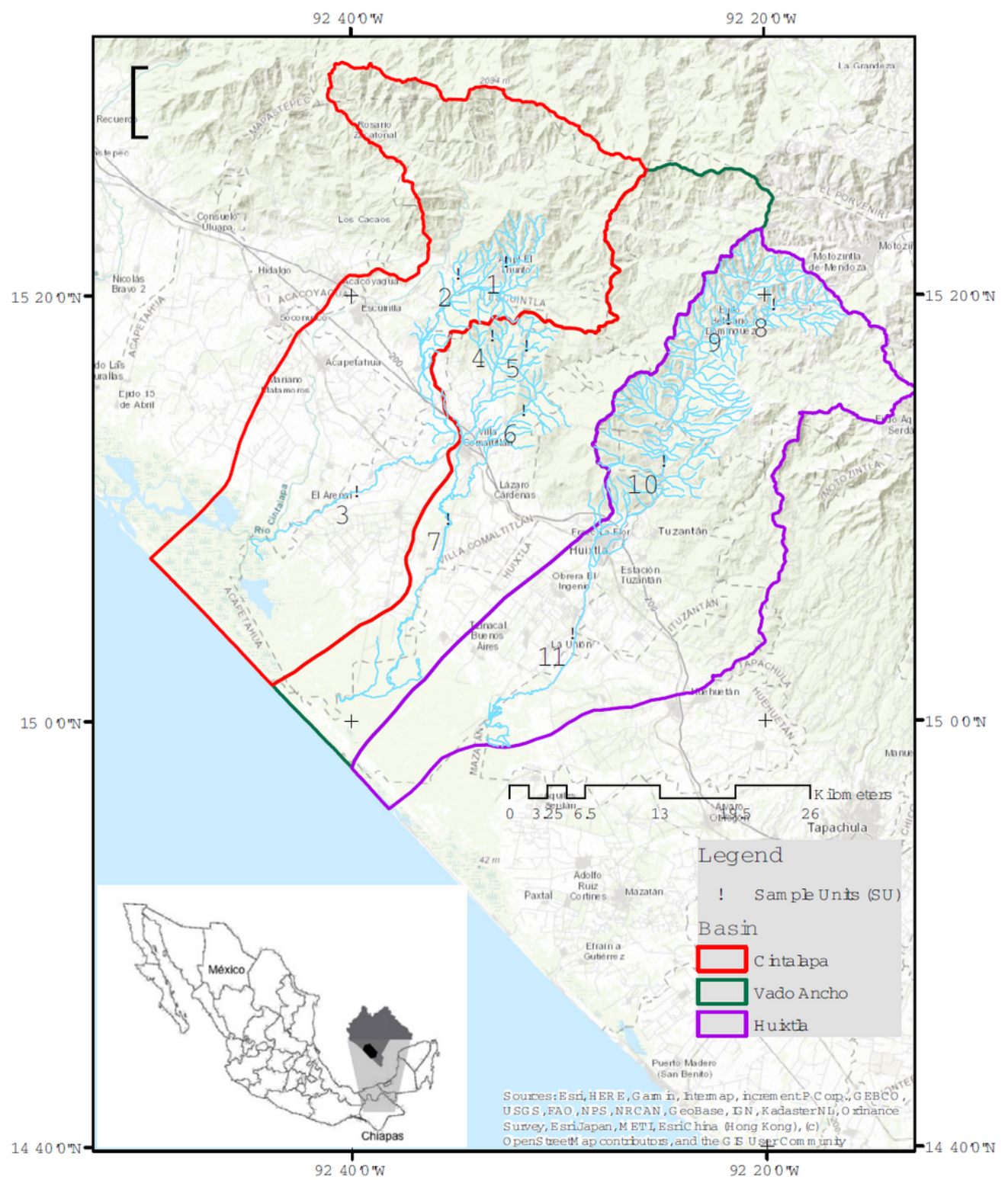

\section{Figure 1}

Location and distribution of sampling units (SU) along the Cintalapa, Vado Ancho and Huixtla Rivers. Black dots correspond to each SU: El Triunfo = 1; Independencia = 2; Puente Teziutlán = 3; Unión Hermosillo = 4; El Recuerdo = 5; Zapote Mocho = 6; El Palmar = 7; Tolimán = 8; Puente Chorro = 9; Huixtla = 10; El Arenal $=11$ 


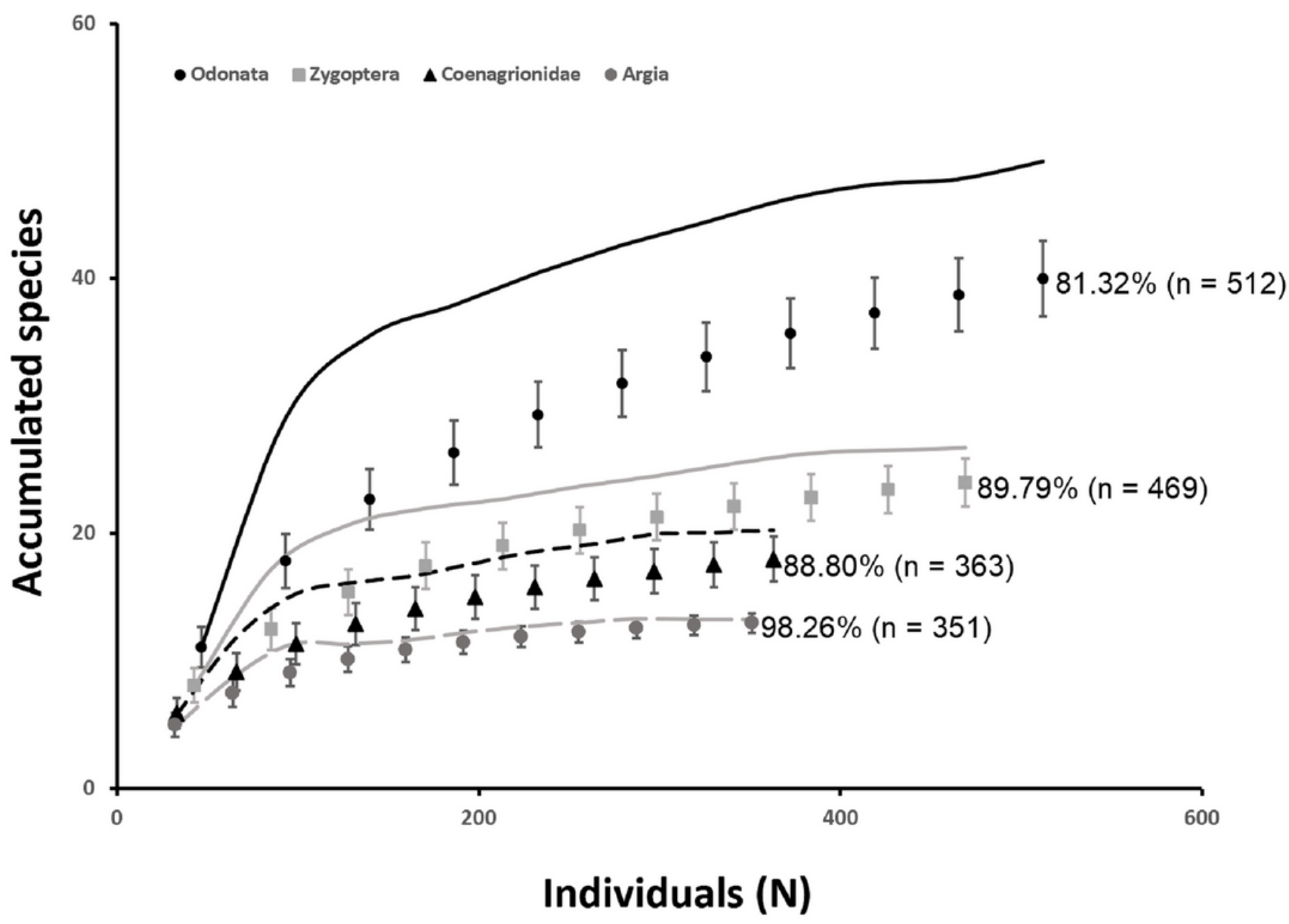

Figure 2

Rarefaction curves for different taxonomic arrangements (Odonata $=$ black dots, Zygoptera $=$ grey squares, Coenagrionidae $=$ black triangles and Argia $=$ grey dots $)$ in each SU. Species richness observed $( \pm$ standard error $)$ versus captured individuals. Lines represents species accumulation based on Chao model two (Odonata = black line, Zygoptera = grey line, Coenagrionidae $=$ black dashed line and Argia $=$ grey dashed line)

a)

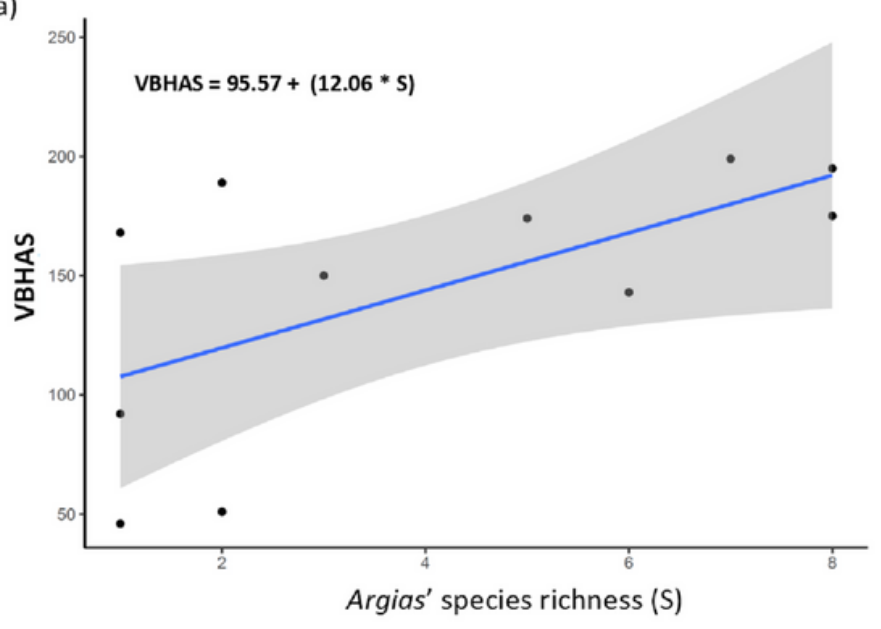

b)

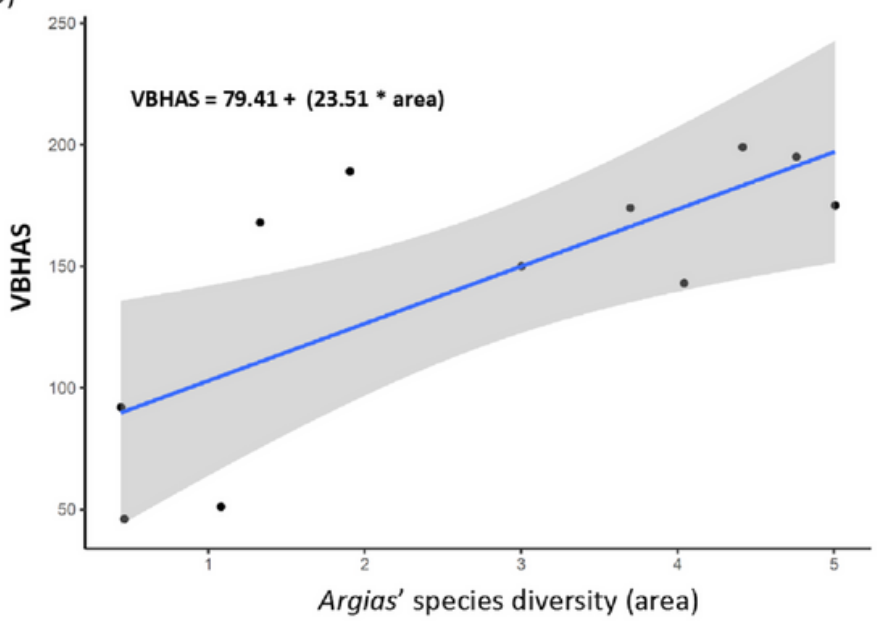

Figure 3 
Generalized linear model analyses of elevation (in meters above sea level, masl), for different taxonomic arrangements in each SU. a) Odonata, b) Zygoptera, c) Coenagrionidae and d) Argia total abundance; e) Odonata species richness (S) and f) diversity (D). The blue line denotes the expected linear regression, black dots correspond to observed values, and grey zones represent the confidence interval at $95 \%$

\section{Supplementary Files}

This is a list of supplementary files associated with this preprint. Click to download.

- SupplementaryMaterialAppendix1.pdf

- SupplementaryMaterialAppendix2.pdf

- SupplementaryMaterialAppendix3.pdf

- SupplementaryMaterialAppendix4.pdf

- SupplementaryMaterialAppendix5.pdf

- SupplementaryMaterialAppendix6.pdf

- SupplementaryMaterialAppendix7.pdf

- SupplementaryMaterialAppendix8.xIsx

- SupplementaryMaterialAppendix9.xlsx 